\title{
Empowering Teacher Candidates to Create Social Justice Curriculum Through Civic Engagement Projects
}

\author{
Gayle Y. Thieman \\ Portland State University
}

The purpose of this research is to examine how participating in a Civic Engagement Project (CEP) led teacher candidates (TCS) to develop and publish race and social justice curriculum. This article describes the CEP, a graduate level social studies methods course assignment for TCs who research community issues, select a class project, collaborate, create and publish resources for educators. This mixed-methods study examines the challenges, benefits and process of the CEP. TCs' reflections, digital curriculum and resources they created, surveys and interviews with TCs after graduation were analyzed through six criteria of anti-racist curriculum, based on Racial Pedagogical Content Knowledge and Critical Race Theory. The intent of this longitudinal research is to analyze the long-term development of social studies teachers across their experiences with civic engagement as pre-service and subsequently in-service teachers.

Keywords: anti-racist curriculum, civic education, civic engagement, counter-narratives, critical race theory, social studies methods, social justice, whiteness studies

\section{INTRODUCTION}

The primary purpose of this research is to examine how participating in a Civic Engagement Project (CEP) during social studies methods coursework led teacher candidates (TCs) to develop and publish race and social justice curriculum. This paper presents a sub-set of the data from a four-year longitudinal study of the CEP in a graduate teacher education program in a mid-size U.S. university. The CEP is a methods course assignment for social studies TCs who research community issues, select a class project, collaborate, create and publish resources for educators. Three research questions guided the inquiry. 1) What challenges, benefits and possible actions did TCs identify in implementing a CEP focused on issues of race and social justice? 2) To what extent did the CEP support the development of anti-racist, social justice curriculum? 3) To what extent did participating in the CEP in social studies methods class prepare TCs to involve their future secondary students in civic engagement and race and social justice curriculum?

Two major research fields ground this study: civic learning/engagement and anti-racist social justice curriculum. A major weakness in civic education is the huge gap in civic education opportunities and civic engagement outcomes across socioeconomic groups (Crocco et al, 2018). While public schools were established to support civic engagement, they actually exacerbate inequality (Levine, 2012) as students who are racially and linguistically diverse are less likely to experience high quality civic education than students who identify as white (Levinson, 2012; Kahne \& Middaugh, 2015). Most beginning teachers lack deep knowledge or skill in teaching about justice, human rights, and public deliberation. According to Hess and Zola (2012), most transformative civic learning programs are teacher-driven and teacher-dependent, but 
few teachers have the opportunity to experience or be mentored in civic engagement pedagogies themselves. Marshall, Manfra, and Simmons (2016) caution, "One of the biggest threats to integration of citizenship education for social justice is a lack of teacher expertise (p.64)." Tyson (2003) advocated for rethinking civic education within a CRT framework; development of citizens would be incomplete without knowledge and skills about the role of race and racism in US history.

Anti-racist social justice curriculum draws upon research in Racial Pedagogical Content Knowledge, Critical Race Theory, and Whiteness Studies. Racial-Pedagogical-Content Knowledge (RPCK) builds on Shulman's (1986) concept of pedagogical content knowledge that focuses on subject matter knowledge for teaching. RPCK calls on teachers to have content knowledge (in the social science disciplines), pedagogical content knowledge, and a working racial knowledge of how race operates within social science, through a Critical Race Theory (CRT) lens (Chandler, 2015). Chandler (2015, pp. 5-6) identified nine concepts of CRT in social studies including: racism is normal and a permanent part of personal belief systems and U.S. institutions; race is a social construct that maintains existing power relationships in society; racial minority interests are accommodated only when they converge with white interests; and social constructs of race, power and privilege can be dismantled through the use of story-telling and counter-story-telling.

CRT challenges color-blindness and asserts racism is endemic, ingrained legally, culturally, and psychologically into all parts of American society (Bell, 2005; Ladson-Billings, 2013). The interaction between race and property maintains racial, economic, and political subordination of people of color (Harris, 1995). Intersectionality focuses on how multiple social identities (race, class, socioeconomic status, gender, ethnicity, heritage language) intersect at the micro level of individual experience to reflect systems of white privilege and oppression (Crenshaw, 1995).

Researchers of Whiteness in Social Studies examine how white teachers enact traditional curriculum as they teach US history from a color-blind perspective that diminishes the impact of race and racism, thereby undermining students' ability to study and critique institutional racism, structural inequality, and power (Wills, 2000). In these teachers' classrooms, white cultural norms, experiences, and stereotypes dominate even as they may seem invisible and are taken-for-granted (Chandler \& Branscombe, 2015).

Crowe \& Cuenca (2016) identify principles of anti-racist curriculum based on Critical Race Theory that informed the TCs' projects in this study. These principles include interrogating power structures and inequalities through critical thinking; focusing on the experiences of historically racialized people and communities; examining intersectionality; illuminating stereotypes and microaggressions against nonwhites; affirming diversity; and teaching empowerment and resistance of racial bias through action. Navarro and Howard (2017) add the CRT tenet of counternarrative which centers the experiential knowledge of people of color and counters majoritarian stories that reinforce racism.

\section{RESEARCH DESIGN}

Responding to the need to understand how teacher candidates experience civic engagement in social studies teacher preparation, the teacher researcher (author) and a co-teaching partner incorporated elements of Project Citizen (Root and Northrup, 2007) in a Civic Engagement Project (CEP) with the teacher candidates (TCs) in a year-long secondary social studies methods course. The TCs researched community problems that impact K-12 student learning, created and published resources for teachers and the local community, and collaborated to advocate policy changes. This longitudinal mixed-methods study examines the CEP in years 2 and 3 of the four-year study when TCs developed social justice curriculum to incorporate state standards and to interrupt racial inequity and white privilege in their schools.

In fall term, TCs completed assigned text reading (Epstein, 2014) and reflection questions focusing on the CEP process. A presentation by middle school teachers and students, who shared their Project Citizen portfolios, provided local context and implementation advice (Anderson, 2017). In year three TCs read an additional text by Agarwal-Rangnath, Dover, and Henning (2016) that focused more explicitly on the voices and experiences of justice-oriented teachers who integrated multiple perspectives, especially those traditionally marginalized and excluded from the curriculum, and who worked collaboratively with their students to enact change in their school/community. 
In winter term, the TCs brainstormed topics and began to explore self-selected community issues they cared about and believed could be actionable projects. The TCs narrowed their focus to a few community issues and formed groups to study problems in more depth. Each group presented their community issue, explaining the problem, sharing research, and arguing persuasively why this problem mattered and should be selected as the class CEP. Through several rounds of discussion and voting TCs selected the class CEP.

In spring term, the TCs developed and implemented an action plan to carry out their CEP. At the final class meeting TCs shared their project with community stakeholders who provided feedback. TCs were invited to sign permission forms to publish their work digitally and complete a post-project survey. The year following graduation, TCs were invited to participate in an interview about the impact the CEP had on their teaching practice.

Of the $31 \mathrm{TCs}$ who agreed to participate in the study, there were 13 white males, 12 white females, four male and two female students of color, representing Latina/o, Asian, Black and Native American identities. One TC self-identified as a gay female. The teacher educators are a cis-gender white female who taught 712 social studies for 13 years and has been teaching social studies methods for 20 years (author), and a cisgender white male who has been teaching high school social studies for seven years and co-teaching social studies methods for three years with the author.

\section{METHODS, DATA, FINDINGS}

In 2018, the TCs decided on a project to interrupt racism in the curriculum and address the negative impact of Eurocentric curriculum on their students of color. The TCs were aware that the state was developing new standards and there was no published curriculum or lessons/resources to support implementation of the curriculum standards. The TCs created and published digital lessons focusing on issues of racial inequity and injustice, providing counter-narratives to traditional curriculum, including the voices of African Americans, Native Americans, Latino/a and Asian American immigrants, rights of those with disabilities and those who identify as LGBTQIA. In 2019, the TCs focused on racial inequity and white privilege in schools, investigating topics such as disproportionate discipline of students of color, racial inequity in the teaching profession as well as the history of racism in the state. The TCs published work is available.

RQ1: What challenges, benefits and possible actions did TCs identify in implementing a CEP focused on issues of race and social justice?

The teacher researcher conducted a content analysis of TCs' written reflections while reading the course text (Epstein, 2014) prior to and during their work on the CEP. While reading each TC's responses to four questions, words or phrases were identified and then overall themes that represented TCs' responses were created (see Table 1).

\section{What Is the Most Significant Challenge of Civic Literacy Projects?}

The TCs' written responses focused on five challenges of implementing civic engagement projects: fear of controversy, district curriculum expectations, deficit view of students, silencing and marginalization of diverse students, and TCs' inexperience. Many of the TCs wrote about administrative and community fears surrounding social issues and controversial topics such as racism, poverty, and homelessness. The TCs perceived a conflict in fitting a CEP into the district-prescribed curriculum and standards that their CTs were required to teach. They also identified a pedagogical conflict between active student engagement in a CEP and the passive student learning role they witnessed in their CTs' classrooms. The TCs identified the power of the banking model (Freire, 1970) and "official knowledge" that silenced and marginalized culturally, racially, and linguistically diverse students. Finally, the TCs worried about their inexperience in conducting a CEP and insufficient time to complete a CEP while student teaching. 


\section{How Would You Describe Two Benefits of Civic Literacy Projects to Your Cooperating Teacher?}

TCs' reflections focused on four potential benefits of civic literacy projects: promotes student empowerment and agency, supports curriculum standards, promotes justice-oriented citizenship, and builds critical thinking skills. The TCs anticipated that the CEP could engage and empower secondary students to develop agency and realize their potential as they took responsibility, engaged in their community in meaningful ways and made decisions and advocated for changes important to them. The TCs also believed that the CEP could connect students and help them become active members of their community. They wrote that the CEP could help students meet district and state curriculum standards and promote citizenship and democracy while building critical thinking skills through authentic intellectual work (Newmann, King, \& Carmichael, 2007).

\section{What Is a Topic You Would Be Interested in Exploring for the CEP?}

TCs proposed five issue-based topics they wanted to explore for a CEP: social, political, economic, environmental and educational justice. The topics that were listed most often were related to social justice: race(ism), racial discrimination, inequities in the community, and sexual harassment; political justice: immigration and police violence; economic justice: health care, food (in)security, gentrification, lack of affordable housing, and homelessness; environmental justice: climate change and environmental protection; and educational justice: multicultural/multiethnic curriculum.

\section{What Are Some Potential Actions We Could Take Related to the CEP?}

TCs' identified three types of actions for a CEP: develop informational products such as webpages, podcasts, and documentaries, create curriculum and lesson plans, and collaborate with public officials and organizations that have a social justice model.

TABLE 1

EXCERPTS FROM TEACHER CANDIDATES' REFLECTIONS ON ASSIGNED TEXT (N=31)

\begin{tabular}{|l|l|}
\hline Challenges & What is the most significant challenge of civic literacy projects? \\
\hline $\begin{array}{l}\text { Fear of } \\
\text { Controversy }\end{array}$ & $\begin{array}{l}\text { administrative and community fears surrounding social issues and controversial } \\
\text { topics such as racism, poverty, homelessness }\end{array}$ \\
\hline $\begin{array}{l}\text { District } \\
\text { Curriculum } \\
\text { Expectations }\end{array}$ & $\begin{array}{l}\text { conflict with fitting a CEP into the district-proscribed curriculum and standards their } \\
\text { cooperating teachers (CTs) are required to teach }\end{array}$ \\
\hline $\begin{array}{l}\text { Deficit View of } \\
\text { Students }\end{array}$ & $\begin{array}{l}\text { underestimating student ability and maturity which leads to a pedagogical conflict } \\
\text { between the passive student learning role TCs witnessed in their CTs' classrooms } \\
\text { and active student engagement in CEP }\end{array}$ \\
\hline $\begin{array}{l}\text { Silencing and } \\
\text { Marginalization } \\
\text { of Diverse } \\
\text { Students }\end{array}$ & $\begin{array}{l}\text { power of the banking model and "official knowledge" that silences and marginalizes } \\
\text { culturally, racially, linguistically diverse students }\end{array}$ \\
\hline $\begin{array}{l}\text { TC } \\
\text { inexperience }\end{array}$ & $\begin{array}{l}\text { TC inexperience in conducting a CEP and not having enough time to complete a } \\
\text { project while student teaching. }\end{array}$ \\
\hline Benefits & $\begin{array}{l}\text { How would you describe two benefits of civic literacy projects to your } \\
\text { Cooperating Teacher? }\end{array}$ \\
\hline $\begin{array}{l}\text { Student } \\
\text { Empowerment } \\
\text { \& Agency }\end{array}$ & $\begin{array}{l}\text { empowering secondary students to develop agency and realize their potential as they } \\
\text { take responsibility, engage in their community in meaningful ways, make decisions } \\
\text { and advocate for changes important to them }\end{array}$ \\
\hline $\begin{array}{l}\text { Supports } \\
\text { Standards }\end{array}$ & \begin{tabular}{l} 
providing scaffolds to meet standards of literacy and civic discourse \\
\hline
\end{tabular} \\
\hline
\end{tabular}




\begin{tabular}{|c|c|}
\hline $\begin{array}{l}\text { Justice-oriented } \\
\text { Citizenship }\end{array}$ & promoting justice-oriented citizenship \\
\hline $\begin{array}{l}\text { Critical } \\
\text { Thinking Skills }\end{array}$ & building critical thinking skills through authentic intellectual work \\
\hline Topics & What is a topic you would be interested in exploring for the CEP? \\
\hline $\begin{array}{l}\text { Social Justice } \\
\text { Issues }\end{array}$ & Race(ism), Racial Discrimination \& Inequities; Sexual Harassment \\
\hline Political Issues & Immigration, Police Violence \\
\hline $\begin{array}{l}\text { Economic } \\
\text { Issues }\end{array}$ & $\begin{array}{l}\text { Health Care, Food (in)Security, Gentrification, Lack of Affordable Housing, } \\
\text { Homelessness }\end{array}$ \\
\hline $\begin{array}{l}\text { Environmental } \\
\text { Issues }\end{array}$ & Environmental Protection, Climate Justice \\
\hline $\begin{array}{l}\text { Educational } \\
\text { Issues }\end{array}$ & Multiethnic Curriculum \\
\hline Actions & What are some potential actions we could take related to the CEP? \\
\hline Products & Create documentary, podcast, informational webpage other educators can access \\
\hline Education & Create curriculum and lesson plans; Write about experiences with race \\
\hline Collaboration & Collaborate with public officials and organizations that have a social justice mode \\
\hline
\end{tabular}

RQ2: To what extent did the TCs' CEPs reflect anti-racist, social justice curriculum?

Drawing upon the work of Agarwal-Rangnath, et. al, (2016), Chandler (2015), Crenshaw (1995), Crowe and Cuenca (2016) and Navarro and Howard (2017) the teacher researcher conducted a content analysis of the lessons and websites developed by the TCs in the 2018 and 2019 CEP through the lens of six criteria:

- interrogates power structures and inequalities

- focuses on experiences of historically racialized and marginalized people

- examines intersectionality

- illuminates stereotypes and microaggressions

- incorporates counter-narratives to the dominant cultural/historical perspective

- teaches empowerment and resistance of racial bias through action

Table 2 includes a subset of the curriculum the TCs created in the 2018 and 2019 Civic Engagement Projects. The content created by the TCs is available online (Thieman, G. 2019).

TABLE 2

SAMPLE SOCIAL JUSTICE CURRICULUM UNITS, LESSON PLANS, WEBPAGES

\begin{tabular}{|l|l|}
\hline Unit Topic Essential Question & Lesson Plans and Webpages \\
\hline $\begin{array}{l}\text { Racial Wealth Gap } \\
\text { Surviving to Thriving: Examining } \\
\text { the Racial Wealth Gap }\end{array}$ & $\bullet \quad$ Who Has What? \\
& - Why is There a Racial Wealth Gap? \\
\hline $\begin{array}{l}\text { Police Violence Mock Trial } \\
\text { When Can the Police Use Force? }\end{array}$ & $\bullet \quad$ What Can Be Done? \\
What Rules Govern Them? & - $\quad$ Praham voling in Your Community \\
& $\bullet \quad$ Police Violence Mock Trial Prep \\
\hline $\begin{array}{l}\text { Impact of Globalization } \\
\text { Is globalization a positive force in } \\
\text { the world? For whom? }\end{array}$ & $\bullet \quad$ What Is Globalization? \\
\hline
\end{tabular}




\begin{tabular}{|c|c|}
\hline & - Globalization in Review-the Positives and Negatives \\
\hline $\begin{array}{l}\text { From Stereotyping to Cultural } \\
\text { Genocide. Is it Possible to } \\
\text { Destroy a Culture While } \\
\text { Preserving the Lives of Those that } \\
\text { Created It? }\end{array}$ & $\begin{array}{l}\text { - American Indian Boarding Schools and Forced Assimilation } \\
\text { - Killers of the Flower Moon: Systemic Racism and the Osage } \\
\text { Reign of Terror } \\
\text { - "Reel Injun": On the Trail of the Hollywood Indian Part I } \\
\text { and II }\end{array}$ \\
\hline $\begin{array}{l}\text { The Evolution of LGBTQIA } \\
\text { Rights } \\
\text { How have the laws and the } \\
\text { interpretation of laws affected the } \\
\text { LGBTQ Community from the } \\
\text { Early } 20^{\text {th }} \text { Century to Now? }\end{array}$ & $\begin{array}{l}\text { - } \text { Analyzing the } 14^{\text {th }} \text { Amendment } \\
\text { - } \quad \text { Analyzing Bowers v Hardwick Supreme Court Case } \\
\text { - } \quad \text { Analyzing the Lawrence v. Texas Supreme Court Case } \\
\text { - } \quad \text { Analyzing the Obergefell v. Hodges Supreme Court Case } \\
\text { - The Equal Rights Amendment }\end{array}$ \\
\hline $\begin{array}{l}\text { History of Racism in Oregon. } \\
\text { How have people of color been } \\
\text { historically treated in Oregon? }\end{array}$ & $\begin{array}{l}\text { - } \text { History of Racism in Oregon, 1804-1867 } \\
\text { - History of Racism in Oregon, 1870-1914 } \\
\text { - } \quad \text { Hidden History of African Americans in Oregon } \\
\text { - } \quad \text { Counter-narrative to Manifest Destiny: Settlement Effect on } \\
\text { - Native American Communities } \\
\text { - } \quad \text { History of Racism in Oregon, 1920's - 1960's } \\
\text { - Racism in Prtland: 1969-1988 } \\
\end{array}$ \\
\hline $\begin{array}{l}\text { Impact of Inequality in Teaching } \\
\text { Why does diversity in teaching } \\
\text { matter and what can be done about } \\
\text { it? }\end{array}$ & $\begin{array}{ll}\text { - } & \text { Root Causes \& Implications of Lack of Diversity } \\
\text { - } & \text { Reflecting on our Educational Experiences } \\
\text { - } & \text { Racial Equity in the Teaching Profession }\end{array}$ \\
\hline $\begin{array}{l}\text { Disproportionate Discipline of } \\
\text { Students of Color }\end{array}$ & $\begin{array}{ll}\text { - } & \text { Educate Yourself } \\
\text { - } & \text { Unconscious Bias Quiz } \\
\text { - } & \text { Questions to Consider } \\
\end{array}$ \\
\hline $\begin{array}{l}\text { Recognizing White Privilege } \\
\text { What is white privilege really? }\end{array}$ & $\begin{array}{l}\text { - Guide to Establishing Empathy \& Recognizing White } \\
\text { Privilege } \\
\text { - How Do we Want to be Treated? } \\
\text { - What is White Privilege? }\end{array}$ \\
\hline Organizations for Social Justice & $\begin{array}{l}\text { - } \quad \text { What Organizations Support Social Justice? } \\
\text { - How Can I get Support (legal assistance, food \& school } \\
\text { supplies, immigration, community services)? } \\
\text { - } \quad \text { How Can I Get Involved (student, teacher, parent)? }\end{array}$ \\
\hline
\end{tabular}

Table 3 presents the degree to which TCs' projects incorporated issues of race and social justice. While few of the curriculum units or web pages addressed all six criteria, about half addressed several criteria and most included counter-narratives. 


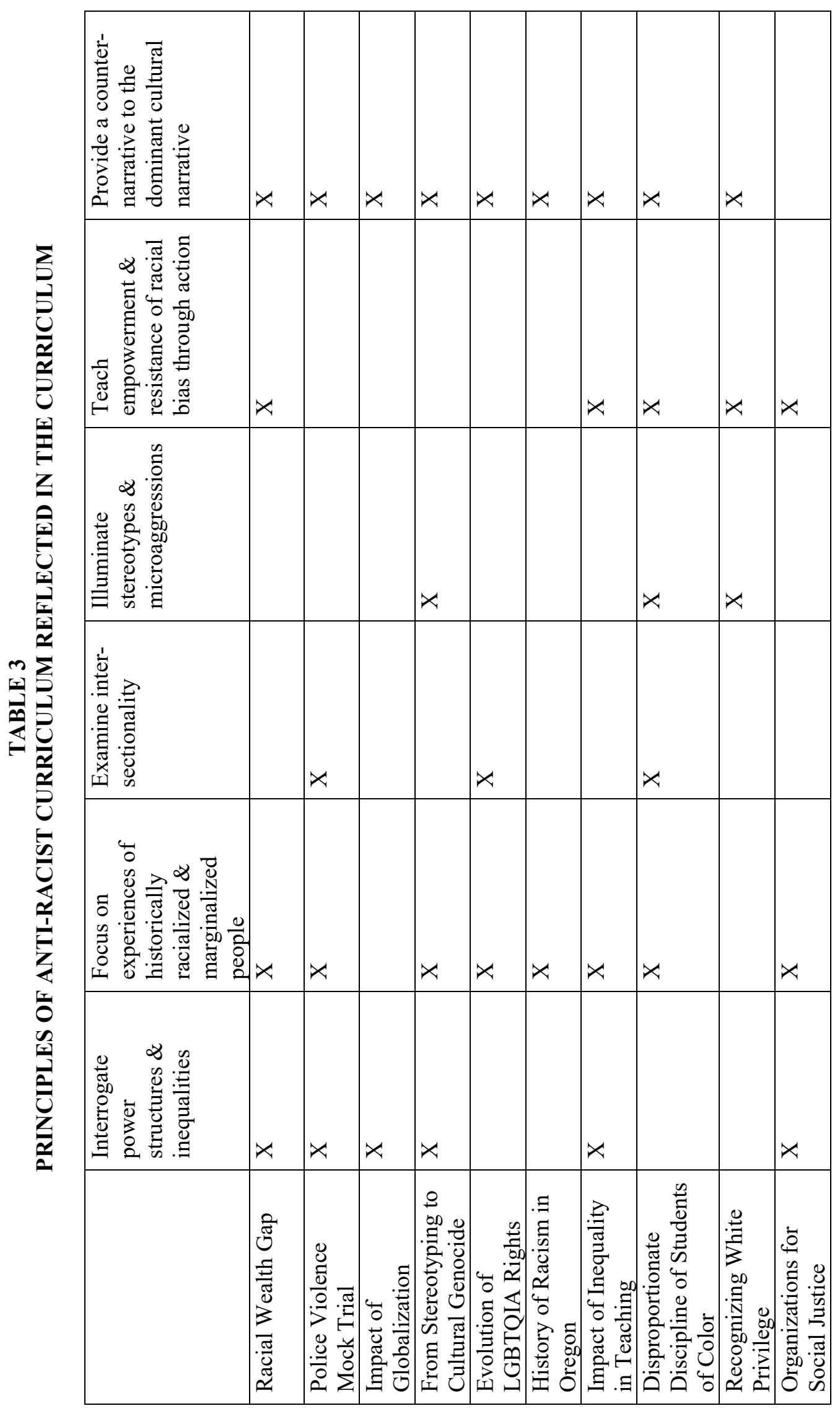

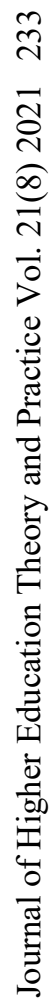


RQ3: To what extent did participating in the CEP in social studies methods class prepare TCs to involve their future secondary students in civic engagement and race/social justice curriculum?

Seventeen of the 31 TCs completed an anonymous online survey after graduation. Survey participants represented $55 \%$ of the total, and some patterns are evident. The majority reported that participating in the CEP positively impacted their ability to research a community problem or issue (13/17), collaborate with others in researching and developing a solution (14/17), and engage in civic discourse (13/17). While the majority of TCs reported that participating in the CEP positively affected their civic knowledge and dispositions, about $1 / 3$ reported no effect. These responses may reflect that all of the TCs were graduate students and some had Master's degrees in history or political science. When asked to what extent participating in the CEP prepared them to involve secondary students in a civic engagement project of some type, only two felt well prepared, while nine indicated they felt somewhat prepared, and five felt a little prepared.

TCs were also asked to participate in follow-up interviews two years after graduation. Two interviews reflect the range of their experiences. Since graduating in 2018, Tien (pseudonym), an Asian American teacher, has taught U.S and world history at a private parochial high school, where she also served as advisor for the Asian American Pacific Islander club. Tien was frustrated by the traditional history curriculum's dominant narrative that focused on Eurocentric content and excluded historically marginalized groups. Instead of a Civic Engagement Project, she helped organize a student-led, school-wide Human Dignity conference for middle school students, that focused on activism, culture, and identity. Tien explained, "It is difficult to have a civically engaged curriculum when so many teachers are outside the conversation." Despite this, Tien did feel her school was making progress in preparing students to take civic action. "It depends on the student and where they are at in their personal journey. Some students are struggling to understand what white privilege is and other students already get it."

Ken (pseudonym), a white male teacher, was a substitute teacher for two years and did not have the opportunity to engage students in a CEP. His participation in the social studies methods class CEP taught him how to set up a class-wide project and how to discuss the importance of civic engagement. Most of the teachers for whom he was substituting were still teaching the dominant narrative that they learned themselves. He was able to see the result of a long-term project in which students created Zines based on topics that interested them such as environmental or LGBTQ rights or their hobbies. [The topics] "ranged from actual civic engagement and political activism to this is what I'm interested in for my project. I saw how the Zine project wrapped up, and it came down to a deeper understanding of the world around them and the social and political structures and systems that we navigate."

\section{CONCLUSION}

This study responds to calls for taking educational responsibility and researching evidence-based action to correct entrenched injustices in teaching social studies. Many teacher candidates (TCs) enter social studies teacher education programs, lacking racial historical knowledge and an inability to identify how race may be taught in K-12 schools. (Demoiny, 2018, p. 331). This study examined the lived experiences of 17 social studies TCs as they explored issues of social justice and racial inequity through the CEP. In both years TCs intentionally designed curriculum and resources to incorporate people of color, women, LGBTQ, immigrants, and other marginalized voices (Navarro and Howard, 2017).

How does this study help us understand how teacher candidates think about social justice in relation to the Civic Engagement Project? Initially the TCs identified four potential benefits of civic literacy projects: promoting student empowerment and agency, supporting curriculum standards, promoting justice-oriented citizenship, and building critical thinking skills. The curriculum, lesson plans, and websites they developed incorporated many of the principles of anti-racist curriculum. Tien and Ken expressed very similar definitions of civic engagement: individuals actively engaging and participating with their community in a meaningful way, using their knowledge and skills, making decisions. However, only Tien specifically critiqued the dominant curriculum narrative and actively worked to create opportunities for her students to 
participate in affinity groups and address issues of racial inequity and social justice through the Human Dignity Summit. Ken's role as a substitute teacher did not support him pushing back against the dominant narrative by integrating the anti-racist curriculum he created as a TC.

The next step in this research is to dig deeper and ask how the CEP can empower agency for TCs to work for change as social studies teachers. The intent of this longitudinal research is to analyze the longterm development of social studies teachers across their experiences with the Civic Engagement Project as pre-service and subsequently in-service teachers. Through the CEP, teacher candidates did the work of informed and engaged citizen scholars. It remains to be seen whether and how they can involve their future students in civic engagement and race and social justice curriculum.

\section{ACKNOWLEDGEMENTS}

The author wishes to acknowledge the graduate students in the 2017-18 and 2018-19 social studies methods classes in the College of Education at Portland State University, whose work is the basis for this research study. The author appreciates the support of co-teacher Benjamin Bruhn who is a high school social studies teacher.

\section{REFERENCES}

Agarwal-Rangnath, R., Dover, A.G., Henning, N. (2016). Preparing to teach social studies or social justice: Becoming a renegade. New York, NY: Teachers College Press.

Anderson, S.K. (2017). Bringing school to life: Place based education across the curriculum. Lanham, MD: Rowman \& Littlefield.

Bell, D.A. (2005). Who's afraid of critical race theory? In R. Delgado \& J. Stefanic (Eds.), The Derrick Bell Reader (pp. 78-83). New York University Press.

Chandler, P.T. (2015). What does it mean to do race in social studies? Racial pedagogical content knowledge. In P.T. Chandler (Ed.), Doing race in social studies: Critical perspectives (pp. 1-10). Charlotte, NC: Information Age Publishing.

Chandler, P.T., \& Branscombe, A. (2015). White social studies: Protecting the white racial code. In P.T. Chandler (Ed.), Doing race in social studies: Critical perspectives (pp. 61-87). Charlotte, NC: Information Age Publishing.

Crenshaw, K. (1995). Mapping the margins: Intersectionality, identity politics, and violence against women of color. In K. Crenshaw, N. Gotanda, G. Peller, \& K. Thomas (Eds.), Critical race theory: The key writings that formed the movement (pp. 357-383). New York, NY: The New Press.

Crocco, M., Segall, A., Halvorsen, A., \& Jacobsen, R. (2018). Deliberating public policy issues with adolescents: Classroom dynamics and sociocultural consideration. Democracy and Education, 26(1), 1-10.

Crowe, A.R., \& Cuenca, A. (Eds.). (2016). Rethinking social studies teacher education in the twenty-first century. Springer International Publishing.

Demoiny, S.B. (2018). Social studies teacher educators who do race work: A racial-pedagogical-content knowledge analysis. Social Studies Research and Practice, 13(3), 330-344.

Epstein, S.E. (2014). Teaching civic literacy projects: Student engagement with social problems. New York, NY: Teachers College Press.

Freire, P. (1970). Pedagogy of the oppressed. New York, NY: The Continuum.

Harris, C.I. (1995). Whiteness as property. In K. Crenshaw, N. Gotanda, G. Peller, \& K. Thomas (Eds.), Critical race theory: The key writings that formed the movement (pp. 276-291). New York, NY: The New Press.

Hess, D., \& Zola, J. (2012). Professional development as a tool for improving civic education. In D. Campbell, M. Levinson, \& F.M. Hess (Eds.), Making civics count: Citizenship education for a new generation (pp. 183-206). Cambridge, MA: Harvard Education Press. 
Kahne, J., \& Middaugh, E. (2015). High quality civic education: What is it and who gets it? Social Education, 72(1), 34-39.

King, L.J., \& Chandler, P.T. (2016). From non-racism to anti-racism in social studies teacher education: Social studies and racial pedagogical content knowledge. In A.R. Crowe \& A. Cuenca (Eds.), Rethinking Social Studies Teacher Education in the Twenty-first Century (pp. 3-21). Springer International Publishing.

Ladson-Billings, G. (2013). Critical race theory--What is it not! In M. Lynn \& A.D. Dixon (Eds.), Handbook of Critical Race Theory in Education (pp. 34-47). New York: Routledge.

Levine, P. (2012). Education for a civil society. In D.E. Campbell, M. Levinson, \& F.M. Hess (Eds.), Making civics count: Citizenship education for a new generation. Cambridge, MA: Harvard Education Press.

Levinson, M. (2012). Diversity and civic education. In D.E. Campbell, M. Levinson, \& F.M. Hess (Eds.), Making civics count: Citizenship education for a new generation. Cambridge, MA: Harvard Education Press.

Marshall, P., Manfra, M.M., \& Simmons, C.G. (2016). No more playing in the dark: Twenty-first century citizenship, critical race theory, and the future of the social studies methods course. In A.R. Crowe \& A. Cuenca (Eds.), Rethinking social studies teacher education in the twenty-first century. Springer International Publishing.

Navarro, O., \& Howard, T.C. (2017). A critical race theory analysis of social studies research theory and practice. In M.M. Manfra \& C.M. Bolick (Eds.), The Wiley Handbook of Social Studies Research. John Wiley \& Sons, Inc.

Newmann, F., King, B., \& Carmichael, D. (2007). Authentic instruction and assessment: Common standards for rigor and relevance in teaching academic subjects. Des Moines IA: Iowa Department of Education.

Root, S., \& Northup, J. (2007). Project Citizen evaluation report: Prepared for Center for Civic Education. Denver, CO: RMC Research Corporation.

Shulman, L.S. (1986). Those who understand: Knowledge growth in teaching. Educational Researcher, $15(2), 4-14$.

Thieman, G. (2019). Serving our students: Resources for educators from educators. Social Justice Curriculum. Retrieved from https://sites.google.com/pdx.edu/psusocialstudies

Tyson, C.A. (2003). A bridge over troubled water: Social studies, civic education, and critical race theory. In G. Ladson-Billings (Ed.), Critical race theory perspectives on social studies: The profession policies, and curriculum. Greenwich, CT: Information Age.

Wills, J.S. (2001). Missing in interaction: Diversity, narrative, and critical multicultural social studies. Theory and Research in Social Education, 29(1), 43-64. 